\title{
Effect of Protein Supplementation on in vitro Maturation of Sheep Oocytes and in vitro Culture of Preimplantation with $\alpha$-Tocopherol Supplementation in CR1 aa Medium on Sheep Embryos to the Blastocyst Stage
}

\author{
Dulam Sreenivas ${ }^{1}$, Kaladhar DSVGK ${ }^{2 *}$, Nagendra Sastry Yarla², Thomas VM1 and PalniSamy A $^{3}$ \\ ${ }^{1}$ Chennai Fertility Centre, Chennai, India \\ ${ }^{2}$ GITAM University, Visakhapatnam, AP, India \\ ${ }^{3}$ Department of Animal Biotechnology, Tamilnadu Veterinary and Animal Sciences University, India
}

\begin{abstract}
Sheep play a vital role within the Indian economy and therefore the production from native breeds is comparatively low because of their poor generative potency. A great challenge of analysis is concerned to beat the constraints within the technology like costly and sophisticated nature of the technology and low success rate. Fetal bovine serum can be supplemented in IVM and IVF media to achieve better maturation and cleavage. Wheat peptone may not produce desired maturation and cleavage when compared to FBS and BSA, and may not be a useful supplement in IVM and IVF. BSA supplementation also yields better maturation and embryo development when compared to wheat peptone but would involve high cost in embryo production. Supplementation of wheat peptones in IVC of embryos yielded better embryo production suggesting that wheat peptones can be an alternative to animal protein in IVC and would help to minimize the cost in embryo production. The studies have shown that CR1aa medium with a-tocopherol at $200 \mu \mathrm{M}$ is a better media for in vitro embryo production in sheep.
\end{abstract}

Keywords: In vitro production; Sheep; a-tocopherol; CR1aa

\section{Introduction}

Sheep were the earliest stock with the procreative potency over different stock like cows and horses [1]. A most of $70-80 \%$ fertility estimates in giant stock wherever fertility rates of 100 percent are regular options in sheep and goats. The trendy day techniques like secretion elicited super-ovulation, organic process detection and embryo manipulations, embryo culture, synchronizations, in vitro fertilization, have culminated into a surprise animal "Dolly", the sheep, on the fifth of July 1996, that was a milestone within the history of biotechnology.

Cloning, deoxyribonucleic acid injections and improvement in productivity through biotechnology [2] approaches has entered into advanced analysis and far info on the utilization of pre-implantation in sheep embryo production for keeps saving biological is on the market. It's a positive gesture in development of reproductive efficiency in sheep and further research has to be established in embryo development. The production of endocrine wealthy milk from goats and blood platelet activating factors production square measure a number of the mile stones of immense increasing biotechnological inventions in bovid replica.

The recovering oocytes subjected to in vitro maturation (IVM), in vitro fertilization (IVF) and in vitro culture (IVC) for 7 days using standard procedures for sheep. Some factor(s) within the culture media, like growth factors within the sera, could have a mitogenic impact on embryonic cells, or it should alter the distribution of cells to the trophectoderm and inner cell mass, leading to increased body growth rates $[3,4]$.

The influence of assorted in vitro procedures on embryo survival and therefore the production of traditional offspring were investigated in sheep [5]. IVM and IVF provided serial embryonic and vertebrate development in sheep no matter the resultant in vivo or in vitro culture treatments. Attachment procedures square measure a lot of cytotoxic for vesicle survival than cryopreservation. Though this, process is resumed in the sheep and none of the sheeps grafted orthotopically became fertile at a synchronised conjugation [6]. Seven months following attachment, oocytes will be collected from heterotopic and orthotopic grafts, matured and a few of them fertilized. This method is also not developed to the blastodermic vesicle stage. Hence, heterotopic attachment could also be another to orthotopic attachment to preserve fertility provided vesicle survival within the grafts has been markedly improved.

IVM, IVF and IVC provide the established procedures for bovine in vitro embryo production throughout main breeding season are conducted on Reindeer oocytes [7]. When $24 \mathrm{~h}$ of maturation and cumulus enlargement was complete, $71 \%$ of the oocytes reached Metaphase II (MII) with extrusion of the primary cell. The chances of fertilization and cleavage in Reindeer oocytes were found as $36 \%$ and $31.8 \%$. During fertilization, two oocytes developed to the morula stage after 7 days of culture

The influence of varied in vitro procedures on embryo survival and therefore the production of traditional offspring were investigated in sheep has been incontestable [5]. The impact of supply of cumulusoocytes-complexes (COCs), maturation and fertilization conditions on biological process ability of Camelus dromedarius embryos was examined and Quality of the ocytes was assessed through IVM, IVF and IVC of COCs [8]. The COCs percentage reaching metaphase II (MII) after $30 \mathrm{~h}$ of maturation was slightly however not considerably higher for in vivo matured oocytes (93\%) than those in vitro matured

*Corresponding author: Kaladhar DSVGK, GITAM Institute of Science, GITAM University, Visakhapatnam, Andhra Pradesh-530045, India, Tel: +91-9885827025; E-mail: dr.dowluru@gmail.com

Received March 21, 2013; Accepted April 26, 2013; Published April 29, 2013

Citation: Sreenivas D, Kaladhar DSVGK, Yarla NS, Thomas VM, PalniSamy A (2013) Effect of Protein Supplementation on in vitro Maturation of Sheep Oocytes and in vitro Culture of Preimplantation with $\alpha$-Tocopherol Supplementation in CR1aa Medium on Sheep Embryos to the Blastocyst Stage. J Aller Ther 4: 133. doi:10.4172/2155-6121.1000133

Copyright: (c) 2013 Sreenivas D, et al. This is an open-access article distributed under the terms of the Creative Commons Attribution License, which permits unrestricted use, distribution, and reproduction in any medium, provided the original author and source are credited. 
Citation: Sreenivas D, Kaladhar DSVGK, Yarla NS, Thomas VM, PalniSamy A (2013) Effect of Protein Supplementation on in vitro Maturation of Sheep Oocytes and in vitro Culture of Preimplantation with $\alpha$-Tocopherol Supplementation in CR1aa Medium on Sheep Embryos to the Blastocyst Stage. J Aller Ther 4: 133. doi:10.4172/2155-6121.1000133

Page 2 of 8

oocytes (84\%).

The present study investigates the production of embryos through IVM/IVF/IVC procedures. The compositions in various culture media differ significantly and the production may vary. Hence the effect of proteins and effect of vitamin E during IVC has to be conducted to improve the production of oocytes and embryos during embryo production.

\section{Materials and Methods}

\section{Collection, transportation and retrieval of ovaries}

Irrespective of age and body condition, the ovaries from sheep were collected from slaughter of Chennai corporation abattoir. The ovaries were selected and brought to the laboratory in a very thermos containing normal saline maintained at $37^{\circ} \mathrm{C}$ and supplemented with $10 \mu \mathrm{l} / \mathrm{ml}$ penicillin-streptomycin.

The extra ovarian tissues were cut off and therefore the ovaries were washed completely beneath running tap water and rinsed five times in normal saline. The ovaries were then kept in a sterile beaker that contains normal saline at $37^{\circ} \mathrm{C}$. The Oocytes were then retrieved by slicing method that has been proposed by Wani et al. [9]. The COCs were then screened using a stereo zoom microscope and transferred into a $35 \mathrm{~mm}$ petridish containing fresh oocyte collection medium.

\section{Classification and grading of oocytes}

Grading of the oocytes was done on the basis of cumulus cells investment and homogeneity of cytoplasm according to Wani et al. [9].

Grade A (Good): Those with over 3 layers of cumulus cells encompassing the oocyte and uniform cytoplasm.

Grade B (Fair): Those with less than 3 layers of cumulus cells encompassing the oocyte and uniform cytoplasm. oocyte

Grade C (Poor): Those with no cumulus cells surrounding the

\section{Effect of various protein supplements on embryo development}

Animal protein supplements and its replacement with plant peptones during IVM, IVF and subsequent embryo development of the ovine oocytes has been designed and evaluated. In each group six replicates were carried out.

Group I: 10\% FBS in maturation, fertilization and culture media [10].

Group II: Maturation, fertilization and culture media with $5 \mathrm{mg} /$ ml BSA-FAF [11].

Group III: $0.18 \mathrm{mg} / \mathrm{ml}$ wheat peptones in maturation, fertilization and culture media [12].

\section{Influence of various protein supplements on nuclear maturation of ovine oocytes}

The animal protein supplements and its replacement with plant peptones during IVM in TCM 199 containing hormones (FSH, LH and estradiol) and epidermal growth factor (EGF) has been designed and evaluated. In each group six replicates were carried out.

Group IV: COCs were matured in the maturation medium that is supplemented with $10 \%$ fetal bovine serum (FBS)

Group V: COCs were matured in the maturation medium that is supplemented with $5 \mathrm{mg} / \mathrm{ml}$ bovine serum albumin-fatty acid free (BSA-FAF)

Group VI: COCs were matured in the maturation medium that is supplemented with $0.18 \mathrm{mg} / \mathrm{ml}$ wheat peptones

\section{Assessment of nuclear maturation}

To determine the nuclear maturation oocytes were stained with Hoechst 33342 (bisBenzimide H33342 trihydrochloride) stain.

Staining of the oocytes with $10 \mu \mathrm{g} / \mathrm{ml}$ Hoechst 33342 for 10 min, placed between slide and coverslip, were examined under Leica microscope equipped with fluorescent illumination (UV 2-A filter block, 330-380 $\mathrm{nm}$ excitation and $420 \mathrm{~nm}$ emission) for second metaphase stage (MII) oocytes. Maturation of the oocytes is assessed by observing extruded first polar body. From the matured COCs, cumulus cells were removed by vortexing.

\section{In vitro maturation of oocytes}

The IVM medium TCM-199 is supplemented with $0.02 \mathrm{IU} / \mathrm{ml}$ of luteinizing hormone (LH), $100 \mathrm{ng} / \mathrm{ml} \mathrm{EGF,} 1 \mu \mathrm{g} / \mathrm{ml}$ of follitropin (FSH), $1 \mu \mathrm{g} / \mathrm{ml}$ of estradiol and $10 \mu \mathrm{l} / \mathrm{ml}$ penicillin-streptomycin. To the medium, $10 \%$ FBS, $5 \mathrm{mg} / \mathrm{ml} \mathrm{BSA}$ and $0.18 \mathrm{mg} / \mathrm{ml}$ wheat peptones were supplemented separately in maturation medium to assess the maturation rate. Nearly $50 \mu \mathrm{l}$ of IVM droplets is prepared in a Petri dish that is overlaid with mineral oil and pre-equilibrated in $\mathrm{CO}_{2}$ incubator for a minimum of $2 \mathrm{~h}$ at $38.5^{\circ} \mathrm{C}$ under $5 \% \mathrm{CO}_{2}$.

The graded and selected oocytes are washed four times in the maturation medium. In a static platform, nearly 10 COCs are transferred to each droplet and allowed to mature at $38.5^{\circ} \mathrm{C}$ in humidified atmosphere under $5 \% \mathrm{CO}_{2}$ for $24 \mathrm{~h}$. $10 \mathrm{ml}$ of maturation medium was prepared freshly before each trial.

\section{Assessment of maturation of oocytes}

The degree of maturation is assessed based on cumulus cell expansion through examination of oocytes under stereo zoom microscope.

Degree 2: The cumulus cells were spread homogenously and clustered cells were no longer present (Full cumulus cell expansion).

Degree 1: The cumulus cells were spread non-homogenously and clustered cells were still present (Moderate cumulus cell expansion).

Degree 0: The cumulus cells are highly adhering to the zona pellucida (Slight or no expansion).

Degree 1 and 2 cumulus expansion oocytes were considered as matured and the maturation rate was expressed as percentage of the total number of oocyte cultured.

\section{Source of semen}

Testis from slaughtered adult rams (one year and above) were washed thoroughly in tap water and transported in a flask containing PBS supplementation with $50 \mu \mathrm{g} / \mathrm{ml}$ gentamicin to the laboratory within $30 \mathrm{~min}$ and used as source of semen.

\section{Collection of cauda epididymal sperm}

The tunica albugenia was removed and the testis was washed thoroughly with tap water and PBS. The cauda epididymis was cleaned with $70 \%$ alcohol. Then the cauda is incised deeply with Bard-Parker 
Citation: Sreenivas D, Kaladhar DSVGK, Yarla NS, Thomas VM, PalniSamy A (2013) Effect of Protein Supplementation on in vitro Maturation of Sheep Oocytes and in vitro Culture of Preimplantation with $\alpha$-Tocopherol Supplementation in CR1aa Medium on Sheep Embryos to the Blastocyst Stage. J Aller Ther 4: 133. doi:10.4172/2155-6121.1000133

Page 3 of 8

blade and the gushing fluid, rich in sperms was flushed into petridish containing sperm wash medium is assessed before processing.

\section{Preparation of motile sperm for fertilization}

The testis was trimmed and the tail of the epididymis likely to contain mature sperm was cut using a sterile blade. The sperm-rich fluid oozed out is directly placed on BSA-free Brackett and Oliphant (BSA free BO) medium (contains $10 \mu \mathrm{g} / \mathrm{ml}$ Heparin and $10 \mathrm{mM}$ caffeine sodium benzoate) in a Petri dish. Sperm selection was carried out in a Percoll density gradient $(45 / 90 \%)$ placed in $\mathrm{CO}_{2}$ incubator at $39^{\circ} \mathrm{C}$ for $2 \mathrm{~h}$. Approximately $2-3 \mathrm{ml}$ of BSA free $\mathrm{BO}$ medium containing the semen sample was layered over the pre-incubated gradient solution in sterile centrifuge tubes, and centrifuged at $1400 \mathrm{rpm}$ for $10 \mathrm{~min}$ at room temperature.

The supernatant was discarded and the sperm sediment is to be rewashed three times by centrifugation at $1400 \mathrm{rpm}$ for $10 \mathrm{~min}$ in BSAfree $\mathrm{BO}$ medium. The final pellet is resuspended in $1 \mathrm{ml}$ of BSA-free BO medium diluted with $1 \mathrm{ml}$ of BO medium containing $20 \mathrm{mg} / \mathrm{ml}$ of BSA supplemented with $10 \mu \mathrm{g} / \mathrm{ml}$ heparin. A final sperm concentration of 1 to $2 \times 10^{6}$ per $\mathrm{ml} \mathrm{BO}$ medium was used for fertilization. Mature sheep COCs is then washed in $\mathrm{BO}$ medium and distributed at the rate of 20/100 $\mu \mathrm{l}$ drop of fertilization medium under mineral oil.

\section{Preparation of fertilization droplets}

Capacitated spermatozoa $(2 \mu \mathrm{l})$ were added to the fertilization drops and incubated for $18 \mathrm{~h}$ at $38^{\circ} \mathrm{C}$ at $5 \% \mathrm{CO}_{2}$.

\section{Morphological evaluation for development of embryos}

In all the experimental groups, cleavage rate was assessed at $48 \mathrm{~h}$ of culture and subsequent embryo development was assessed every 24 $\mathrm{h}$ post insemination up to 5-6 days. The number of embryos at various stages (2-, 4-, 8- and 16- celled) and morula were recorded.

\section{Effect of various protein supplements}

In vitro developmental rates of ovine zygotes were compared in culture media that are supplemented separately with FBS, BSA and wheat peptones.

The IVM is assessed in TCM-199 supplemented with $1 \mu \mathrm{g} / \mathrm{ml}$ of FSH, $0.02 \mathrm{IU} / \mathrm{ml}$ of LH, $1 \mu \mathrm{g} / \mathrm{ml}$ of estradiol, $100 \mathrm{ng} / \mathrm{ml} \mathrm{EGF}$ and 10 per cent FBS and IVF was done using Fertilization-Tyrode Albumin Lactate and Pyruvate (IVF-TALP) medium supplemented with BSA. In each group six replicates were carried out.

Group VII: 10\% FBS in culture media

Group VIII: $5 \mathrm{mg} / \mathrm{ml}$ BSA-FAF in culture media

Group IX: $0.18 \mathrm{mg} / \mathrm{ml}$ wheat peptones in culture media

In all the experimental groups, cleavage rate was assessed at $48 \mathrm{~h}$ of culture and subsequent embryo development was assessed every 24 $\mathrm{h}$ post insemination up to 5-6 days. The number of embryos at various stages viz. 2-, 4-, 8-16 cell and morula were recorded.

\section{Effect of culture media for development of embryos}

Various media are prepared and the concentrations were standardized. Various media were added to oocyte maturation medium followed by culture in $20 \% \mathrm{O}_{2}$ environment.

\section{TCM-199}

The composition of TCM-199 has been presented in table 1.

\begin{tabular}{|c|c|}
\hline Component g/L & TCM 199 M2154 \\
\hline \multicolumn{2}{|l|}{ (A) Elements } \\
\hline Calcium chloride. $2 \mathrm{H}_{2} \mathrm{O}$ & 0.265 \\
\hline Ferric nitrate. $9 \mathrm{H}_{2} \mathrm{O}$ & 0.00072 \\
\hline Magnesium sulfate (anhydrous) & 0.09767 \\
\hline Potassium chloride & 0.4 \\
\hline Sodium acetate (anhydrous) & 0.05 \\
\hline Sodium bicarbonate & 2.2 \\
\hline Sodium chloride & 6.8 \\
\hline Sodium phosphate monobasic (anhydrous) & 0.122 \\
\hline \multicolumn{2}{|l|}{ (B) Amino acids } \\
\hline DL-Alanine & 0.05 \\
\hline L-Arginine. $\mathrm{HCl}$ & 0.07 \\
\hline DL-Aspartic acid & 0.06 \\
\hline L-Cysteine. $\mathrm{HCl} . \mathrm{H}_{2} \mathrm{O}$ & 0.00011 \\
\hline L-Gystine. $2 \mathrm{HCL}$ & 0.026 \\
\hline DL-Glutamic acid & 0.1336 \\
\hline Glycine & 0.05 \\
\hline L-Histidine. $\mathrm{HCl} . \mathrm{H}_{2} \mathrm{O}$ & 0.02188 \\
\hline Hydroxy-L-Proline & 0.01 \\
\hline DL-Isoleucine & 0.04 \\
\hline DL-Leucine & 0.12 \\
\hline L-Lysine. $\mathrm{HCl}$ & 0.07 \\
\hline DL-Methionine & 0.03 \\
\hline DL-Phenylanlanine & 0.05 \\
\hline L-Proline & 0.04 \\
\hline DL-Serine & 0.05 \\
\hline DL-Threonine & 0.06 \\
\hline DL-Tryptophan & 0.02 \\
\hline L-Tyrosine $2 \mathrm{Na} .2 \mathrm{H} 2 \mathrm{O}$ & 0.05766 \\
\hline DL-Valine & 0.05 \\
\hline \multicolumn{2}{|l|}{ (C) Vitamins } \\
\hline Ascorbic Acid. $\mathrm{Na}$ & 0.0000566 \\
\hline D. Biotin & 0.00001 \\
\hline Calciferol & 0.0001 \\
\hline Choline chloride & 0.0005 \\
\hline Folic acid & 0.00001 \\
\hline Menadione (sodium bisulfite) & 0.000016 \\
\hline Myo. inositol & 0.00005 \\
\hline Niacinamide & 0.000025 \\
\hline Nicotinic acid & 0.000025 \\
\hline P. Amino benzoic acid & 0.00005 \\
\hline D. Pantothenic acid (hemi-calcium) & 0.00001 \\
\hline Pyridoxal. $\mathrm{HCl}$ & 0.00025 \\
\hline Pyridoxine. $\mathrm{HCl}$ & 0.00025 \\
\hline Retinol acetate & 0.00014 \\
\hline Riboflavin & 0.00001 \\
\hline DL-a-Tocopherol phosphate. $\mathrm{Na}$ & 0.00001 \\
\hline Thiamine. $\mathrm{HCl}$ & 0.00001 \\
\hline
\end{tabular}

Table 1: The composition of TCM-199.

The TCM-199 media contains various micro and macro elements along with amino acids and Vitamins. These components act as the source of embryo development. Availability of vitamins in lower levels may not be sufficient at normal conditions.

Preparation of standards can be done using following procedures

\section{- ITS (Insulin Transferrin Sodium Selenite}

1. Let the vial with ITS equilibrate to room temperature

2. Dissolve the Its in $5 \mathrm{ml}$ sterile water after dissolve the ITS in $5 \mathrm{ml}$ 
Citation: Sreenivas D, Kaladhar DSVGK, Yarla NS, Thomas VM, PalniSamy A (2013) Effect of Protein Supplementation on in vitro Maturation of Sheep Oocytes and in vitro Culture of Preimplantation with $\alpha$-Tocopherol Supplementation in CR1aa Medium on Sheep Embryos to the Blastocyst Stage. J Aller Ther 4: 133. doi:10.4172/2155-6121.1000133

Page 4 of 8

sterile water and keep it at room temperature for 30-60 min.

3. Aliquot $\left(10 \mu \mathrm{l}\right.$ portions) and store at $-20^{\circ} \mathrm{C}$ (6 Months).

\section{- EGF (Epidermal Growth Factor)}

1. Let he vial with EGF equilibrate to room temperature

2. Wip top of vial with $70 \%$ ethanol

3. Add $10 \mathrm{ml} 0.9 \% \mathrm{NaCl}$ using a syringe and needle to the vial and dissolve

4. Aliquot (50 $\mu \mathrm{l}$ portions) and store at $-20^{\circ} \mathrm{C}(2$ months $)$ with 10 $\mathrm{ng} / \mu \mathrm{l}$.

\section{- Gentamycin}

Gentamycin $50 \mathrm{mg} / \mathrm{ml}$ normal saline, stored in refrigerator.

\section{TCM-199+}

Composition of TCM-199+has been shown in table 2.

- Preparation: Add the components as per the above concentration filter using Millipore and pour into $5 \mathrm{ml}$ conical tube. Store the medium at 0 to $4^{\circ} \mathrm{C}$ for one week.

\section{TCM-199-}

Composition of TCM-199-has been shown in table 3.

- Preparation: Add the components as per the above concentration filter using Millipore and pour into $5 \mathrm{ml}$ conical tube. Store the medium at 0 to $4^{\circ} \mathrm{C}$ for 1 week.

\section{CRlaa}

Composition of CR1aa has been shown in table 4 .

\begin{tabular}{|l|c|}
\hline Components & Volume \\
\hline TCM -199 & $50 \mathrm{ml}$ \\
\hline FCS & $5 \mathrm{ml}$ \\
\hline ITS & $10 \mu \mathrm{l}$ \\
\hline EGF & $50 \mu \mathrm{l}$ \\
\hline Gentamycin & $500 \mu \mathrm{l}$ \\
\hline
\end{tabular}

Table 2: Composition of TCM-199+.

\begin{tabular}{|l|c|}
\hline Components & Volume \\
\hline TCM -199 & $50 \mathrm{ml}$ \\
\hline FCS & $5 \mathrm{ml}$ \\
\hline Gentamycin & $500 \mu \mathrm{l}$ \\
\hline
\end{tabular}

Table 3: Composition of TCM-199-.

\begin{tabular}{|l|l|}
\hline Components & Volume $\mathbf{~ g} / \mathbf{2 5} \mathbf{~ m l}$ \\
\hline $\mathrm{NaCl}$ & $167.5 \mathrm{mg} / \mathrm{ml}$ \\
\hline $\mathrm{KCl}$ & $5.8 \mathrm{mg}$ \\
\hline $\mathrm{NaHCO}_{3}$ & $55 \mathrm{mg}$ \\
\hline $\mathrm{BSA}$ (Fatty Acid Free) & $75 \mathrm{mg}$ \\
\hline Hemi-Ca Lactate & $13.8 \mathrm{mg}$ \\
\hline Pyruvate & $1 \mathrm{mg}$ \\
\hline L-Glutamine & $3.8 \mathrm{mg}$ \\
\hline Basal Medium Eagle (BMA) (50X Stock) amino acids & $500 \mu \mathrm{l}$ \\
\hline $\begin{array}{l}\text { Minimum Essential medium (MEM) amini acids } \\
\text { (100X stock) }\end{array}$ & $250 \mu \mathrm{l}$ \\
\hline Gentamycin & $12.5 \mu \mathrm{l}$ \\
\hline EGF & $25 \mu \mathrm{l}$ \\
\hline ITS & $5 \mu \mathrm{l}$ \\
\hline
\end{tabular}

Table 4: Composition of CR1aa.
- Preparation: Add the components as per the above concentration filter using Millipore and pour into $5 \mathrm{ml}$ conical tube. Store the medium at 0 to $4^{\circ} \mathrm{C}$ for 1 week.

\section{Effect of culture media with vitamins on embryo development}

a-tocopherol separately at $0,50,100,200$ and $400 \mu \mathrm{M}$ concentrations were added to oocyte maturation medium followed by culture in $20 \%$ $\mathrm{O}_{2}$ environment. The formulation of media with $a$-tocopherol has been experimented for better understanding of requirement in embryo development.

\section{Statistical analysis}

Statistical analysis of data was done according to the Snedecor and Cochran method [12]. The percentage mean value of standard error (mean $\% \pm$ S.E) was calculated for fertilization rates of oocytes and developmental rates of the embryonic stages.

\section{Results}

\section{Recovery rate of different grades of ovine oocytes by slicing} technique

The number and recovery rate of ovine oocytes following slicing technique is presented. Using slicing technique, around 1,407 oocytes were isolated from 341 sheep ovaries with an average of 4.13 oocytes per ovary. By slicing technique 546 (38.81\%), 648 (46.06\%) and 213 (15.14\%) oocytes has been classified as grade A, B and C respectively (Figure 1).

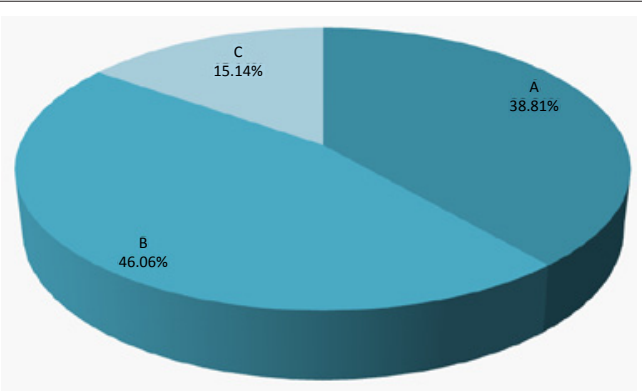

Figure 1: Percentage of different grades of Ovine oocytes recovered by slicing technique.

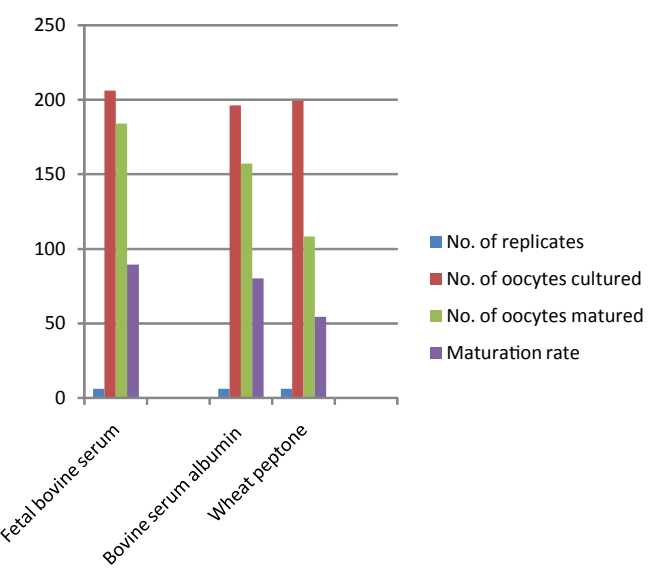

Figure 2: Maturation rate of ovine oocytes in media supplemented with various proteins. 
Citation: Sreenivas D, Kaladhar DSVGK, Yarla NS, Thomas VM, PalniSamy A (2013) Effect of Protein Supplementation on in vitro Maturation of Sheep Oocytes and in vitro Culture of Preimplantation with a-Tocopherol Supplementation in CR1aa Medium on Sheep Embryos to the Blastocyst Stage. J Aller Ther 4: 133. doi:10.4172/2155-6121.1000133

\section{Influence of protein supplements and analyzing maturation rate of ovine oocytes}

The effect of animal protein supplements and its replacement with plant peptones during IVM of ovine oocytes is presented. Out of 206 oocytes cultured in Group I, 184 oocytes matured with a mean maturation percentage of $89.32 \pm 1.67$. Out of 196 oocytes cultured in Group II, 157 oocytes matured with a mean maturation percentage of $80.10 \pm 1.64$. Out of 199 oocytes cultured in Group III, 108 oocytes matured with a mean maturation percentage of $54.27 \pm 1.81$ (Figure 2).

The maturation rate of oocyte was significantly higher in the FBS supplemented group when compared with BSA and wheat peptone supplemented groups.

The observation of matures and immature ovaries and the final observation of matures single polar body has been shown from figure 3 .

\section{Effect of protein supplements on IVF and subsequent embryo development}

The in vitro fertilization and developmental rates of ovine oocytes under three different protein supplements are presented in table 5 . The number of oocytes produced from FBA, BSA and Wheat peptones from six replicates are 184, 157 and 108 respectively. The fertilization rates in media supplemented with FBS is found significant compared to BSA+FAF or Wheat peptones (Table 5).

Figure 4 shows the isolation and identification of sperms, fertilization and final occurrence of two celled embryos. The fertilized oocytes with six replicates has observed highest fertilization rate in FBS (75.00 \pm 1.88$)$ compared with the other two protein supplements rich as BSA $(52.87 \pm 2.04)$ and wheat peptones $(44.44 \pm 0.77)$.
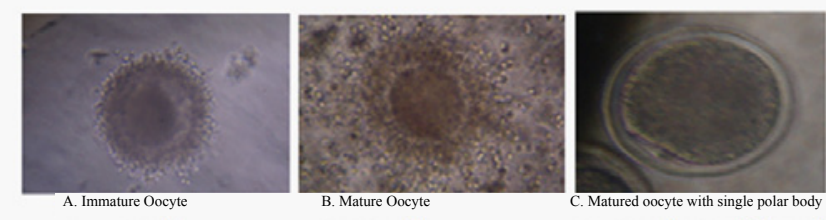

Note: A. Immature oocyte B. Mature oocyte has been represented after removing cumulus cells for observation of single polar body in oocyte Figure 3: Mature and Immature Oocytes.

\begin{tabular}{|l|l|l|l|}
\hline Supplement & $\begin{array}{l}\text { No. of } \\
\text { replicates }\end{array}$ & $\begin{array}{l}\text { No. of } \\
\text { oocytes }\end{array}$ & $\begin{array}{l}\text { No. of two cells } \\
\text { (mean\% } \pm \text { S.E.) } \\
\text { (Fertilized oocytes) }\end{array}$ \\
\hline Fetal bovine serum (Group I) & 6 & 184 & $138(75.00 \pm 1.88)$ \\
\hline Bovine serum albumin (Group II) & 6 & 157 & $83(52.87 \pm 2.04)$ \\
\hline Wheat peptone (Group III) & 6 & 108 & $48(44.44 \pm 0.77)$ \\
\hline
\end{tabular}

Table 5: Mean \pm S.E. percentage of fertilization rate and embryo development of ovine-oocytes in media supplemented with various proteins.
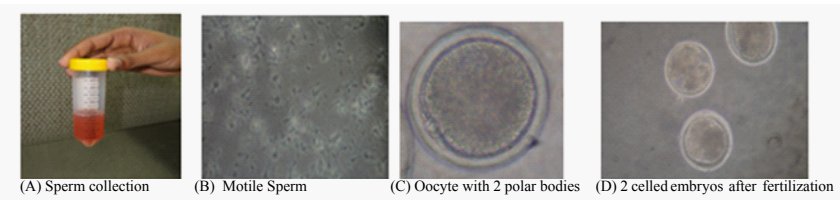

Figure 4: Sperm isolation and Fertilization.

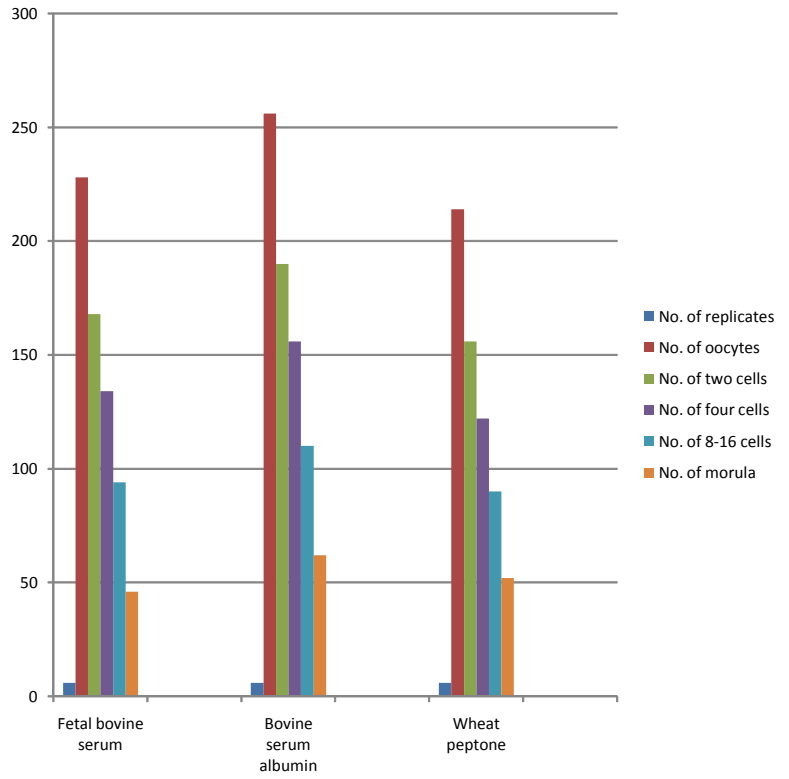

Figure 5: Cleavage rate and morula development of ovine oocytes in media supplemented with various proteins.

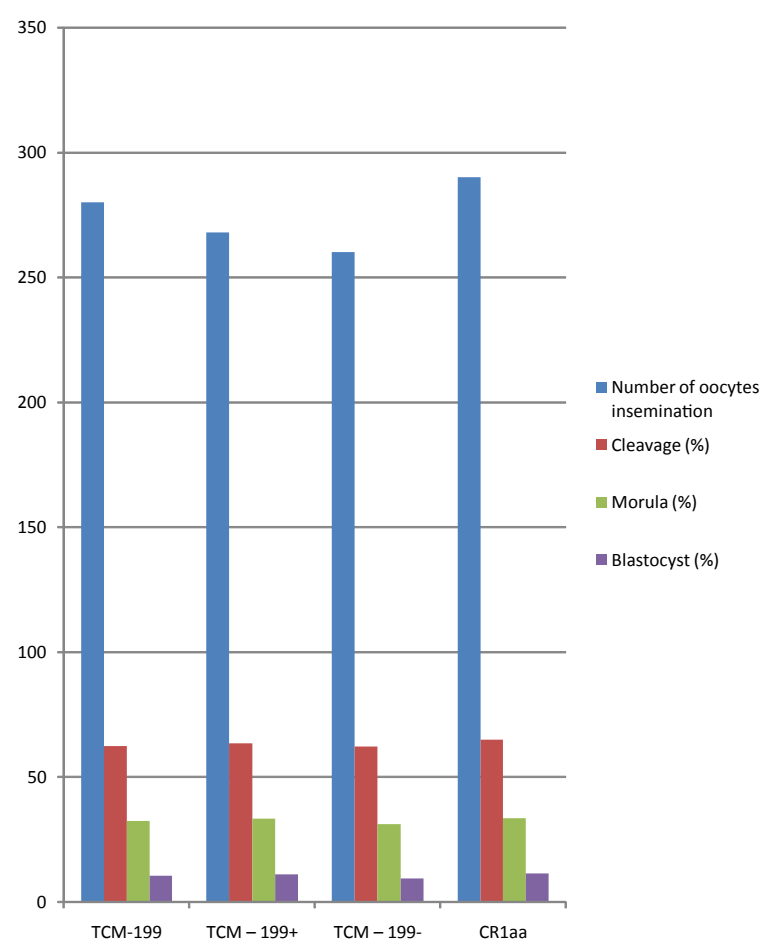

Figure 6: Effect of different media on development of sheep embryos.

Effect of protein supplements in IVC media on subsequent embryo development

The developmental rates of presumptive zygotes under different supplements are presented. In the FBS supplemented group (Group VII), the developmental rates of 2-, 4-, 8-16 cell and morula stages were $73.58 \pm 2.92,58.77 \pm 2.01,41.22 \pm 1.68$ and $20.17 \pm 0.76$ per cent (mean \pm SE), respectively. In BSA-FAF group (Group VIII), the developmental rates of 2-, 4-, 8-16 cell and morula stages were 74.22 $\pm 2.56,60.93 \pm$ 
Citation: Sreenivas D, Kaladhar DSVGK, Yarla NS, Thomas VM, PalniSamy A (2013) Effect of Protein Supplementation on in vitro Maturation of Sheep Oocytes and in vitro Culture of Preimplantation with $\alpha$-Tocopherol Supplementation in CR1aa Medium on Sheep Embryos to the Blastocyst Stage. J Aller Ther 4: 133. doi:10.4172/2155-6121.1000133

Page 6 of 8

\begin{tabular}{|c|c|c|c|c|}
\hline Conc. $(\mu \mathrm{M})$ & \multicolumn{4}{|c|}{$\begin{array}{c}\text { Vitamin E } \\
\text { (or } \alpha \text {-tocopherol) }\end{array}$} \\
\cline { 2 - 5 } & $\begin{array}{c}\text { Number of } \\
\text { oocytes } \\
\text { insemination }\end{array}$ & $\begin{array}{c}\text { Cleavage } \\
\text { (mean\% } \pm \text { S.E.) }\end{array}$ & $\begin{array}{c}\text { Morula } \\
\text { (mean\% } \pm \text { S.E.) }\end{array}$ & $\begin{array}{c}\text { Blastocyst } \\
\text { (mean\% } \pm \text { S.E.) }\end{array}$ \\
\hline 0 & 284 & $64.6 \pm 1.5$ & $33.5 \pm 1.4$ & $11.4 \pm 1.2$ \\
\hline 50 & 286 & $64.9 \pm 1.7$ & $34.1 \pm 1.6$ & $12.5 \pm 1.5$ \\
\hline 100 & 290 & $65.7 \pm 1.2$ & $36.0 \pm 1.3$ & $12.9 \pm 1.0$ \\
\hline 200 & 284 & $67.0 \pm 1.1$ & $37.5 \pm 1.9$ & $14.8 \pm 1.2$ \\
\hline 400 & 276 & $64.7 \pm 1.3$ & $33.8 \pm 1.4$ & $11.6 \pm 1.1$ \\
\hline
\end{tabular}

Table 6: Effect of Vitamins on CR1aa in development of sheep embryos.

$2.55,42.97 \pm 2.20$ and $24.21 \pm 1.28$ per cent (mean \pm SE), respectively. In wheat peptones group (Group IX), the developmental rates of 2-, $4-, 8-16$ cell and morula stages were $72.89 \pm 1.09,57.01 \pm 0.76,42.05 \pm$ 0.36 and $24.29 \pm 0.55$ per cent (mean \pm SE), respectively (Figure 5 ). The number of morula developed was found to be higher in wheat peptone supplemented group followed by BSA and control groups.

The cleavage, morula and blastocyst percent has shown high in CR1aa medium followed by TCM-199+, TCM-199 and TCM199- (Figure 6). CR1aa medium with $a$-tocopherol has shown higher cleavage, morula and blastocyst percent at $200 \mu \mathrm{M}$ concentration (Table $6)$.

\section{Discussion}

Sheep play a crucial role within the Indian economy by providing employment to large population of marginal and landless farmers. Embryos Transfer Technology (ETT) helps in quicker multiplication of elite animal to extend genetic gain. For sustainable and eco-friendly animal production system, differing types of biotechnology tools were introduced to increase meat and milk production $[13,14]$. The modern day technique in Biotechnology leads to develop 'Dolly' in July 1996. The in vitro Embryo production (IEP) in Ovine requires the development of maturation, fertilization and culture media particularly to extend cleavage and development rates by the employment of biological research and transgenesis, that intern improved productivity or high commercial value results demand animals of high genetic value [15]. Hence, the knowledge of the Ovine Physiology from the breeds developed in India from few decades.

The IVF needs the conditions that support motility and capacitation of spermatozoa and maintain the viability of the oocytes to be fertilized. The IVC possess a essential importance to develop and produce the embryo and the culture media continued all needs for embryo development. Mammalian embryos in the past are susceptible to damage from reactive oxygen species and they increase the production of oxygen free radicals when cultured in vitro. The sublethal damage may harmfully affect embryonic development, leading to retarded development, perturbation of traditional metabolic pathways [16].

Vitamins $\mathrm{C}$ and $\mathrm{E}$ docking with metal ions and preventing metalcatalyzed reactions that generate reactive oxygen species (ROS) by IVM of superior grade oocytes in four different media with supplementation of $a$-tocopherol or L-ascorbic acid [17,18]. IVF of sheep embryos using fresh semen collected and capacitated from slaughtered ram testis in above said media has been experimented in the present research by IVC of sheep embryos in different media with above mentioned supplementation.

In the present study, there is highly significant difference in the maturation rate and were considerably higher in FBS group compared with supplementation of BSA and wheat peptones. A higher maturation rate in FBS group may be due to cumulative effect of hormonal factors [19]. The cleavage rate and morula development is found to be considerably higher within the FBS group followed by BSA and wheat peptone supplemented group). The effect of FBS and estrus sheep serum (ESS) on IVM of sheep oocytes shows that ESS could support the in vitro maturation of the oocytes slightly better [20].

In the present study, an average yield of 4.13 oocytes per ovary was obtained by slicing technique. Different oocyte recovery rate has been reported in the past: 6.4 [21], 9.4 [22] and 6.3 [23].

By slicing the ovary, follicles embedded deeply in the cortex were released and slicing was the efficient method in terms of oocyte yield and quality $[24,25]$. The oocyte recovery rate obtained in our study was lower when compared with the recovery rate of 9.4 oocytes per ovary [22] and 6.3 [26] and the difference observed in oocyte recovery rate might be due to the differences in breed, season, ovarian status and age.

Oocytes for in vitro maturation are typically selected supported their cumulus investment and homogeneity of cytoplasm. The gap junctions between oocyte and cumulus cells were needed for the transport of growth factors and hormones necessary for normal maturation and developmental competence $[27,28]$. The gap junctions between the cumulus cells and therefore the oocytes play a necessary role within the transmission of meiosis activating components. The ability of ovine oocytes in beginning of meiosis is interrupted within the absence of initial affiliation between the cumulus cells and therefore the oocyte [23]. Considering the above findings, in the present study, $546 \mathrm{~A}$ grade and $648 \mathrm{~B}$ grade oocytes with uniform cytoplasm, invested by cumulus cells were selected for further maturation. The oocytes of two grades A and B has been considered for the IVM. Grade C has not been considered during IVM.

In the present study there was a highly significant difference in the maturation rate between groups. The maturation rate was significantly higher in the FBS group and supplementation of BSA and wheat peptones did not significantly improve the maturation rate. The major functions of serum are to provide hormonal factors which stimulate cell growth and proliferation, promotes differentiated functions, transport proteins carrying hormones, minerals trace elements, lipids, attachment and spreading factors and stabilizing and detoxifying factors [19]. The highest maturation rate observed in FBS group may be due to the cumulative effect of the above factors which could have caused better cumulus expansion.

Bovine serum albumin may cause the media semi-defined since commercially available preparations were found to be contaminated with some low molecular weight compounds [29] and further BSA also decreased the developmental capacity of the oocytes [30], which could possibly be the reasons for reduced maturation. Since no controlled studies on supplementation of wheat peptones in maturation media are available and based on the present study it can be inferred that addition of wheat peptones to maturation media may not have beneficial effect on oocyte maturation [31]. However, more controlled and elaborate studies are further needed in this regard.

There was a highly significant difference in the cleavage rate and morula development between groups. The cleavage rate and morula development was found to be significantly higher in the FBS group followed by BSA and wheat peptone supplemented group. The factors leading to improved embryo development in serum containing culture medium are not well understood [32]. It is found that block to embryo development occurred around the time of embryonic genome and supplement of serum prevents this block [33,34]. 
Citation: Sreenivas D, Kaladhar DSVGK, Yarla NS, Thomas VM, PalniSamy A (2013) Effect of Protein Supplementation on in vitro Maturation of Sheep Oocytes and in vitro Culture of Preimplantation with $\alpha$-Tocopherol Supplementation in CR1aa Medium on Sheep Embryos to the Blastocyst Stage. J Aller Ther 4: 133. doi:10.4172/2155-6121.1000133

BSA showed no significant embryo promoting effect on postcleavage embryo development compared to FBS $[35,36]$. In addition, the embryotrophic effects of BSA might vary between suppliers and even between lots, which could be the possible reasons for the reduced cleavage rate and morula development [29]. Addition of wheat peptones during IVM, IVF and IVC did not improve the cleavage rate and morula yield. Culture media such as CR1 media on developmental competence and cell apoptosis produced better fertilized embryos through in vitro process [37]. Since no controlled studies on wheat peptone supplementation are available no definite conclusion could be drawn.

In the present study, the nuclear maturation rate was significantly higher in the FBS supplemented group followed by BSA and wheat peptone supplemented groups. The higher maturation rate observed in this study in FBS supplemented group could be due to varying concentrations of hormones, trace nutrients and proteins present in serum which were bound to favor nuclear maturation [38]. Since wheat peptones did not result in significant cumulus expansion, its effect on nuclear maturation was also studied which showed no beneficial effect.

Significant difference was not been observed in the cleavage rate and morula development between groups. However, morula development was found to be higher in wheat peptone supplemented group followed by BSA and FBS supplemented group. In embryo culture, wheat peptone supplementation could be a good alternative to other protein supplements. The wheat peptones may supply nutrients, adhesion components or growth factor analogues which enhances the embryo production [39]. Moreover, hydrolyzed plant proteins have anti-apoptotic properties [40] and protective function over metal ions, potential anti-oxidant properties [41] and contains numerous free amino-acids, short oligopeptides, some vitamins and carbohydrates [42] which may cumulatively be responsible for improved embryo production observed in the study.

in vitro production of sheep embryos and effect of the exogenous addition of $200 \mu \mathrm{M} / \mathrm{ml}$ cysteamine and $20 \mathrm{ng} / \mathrm{ml}$ epidermal growth factor [43] results have indicated that EGF plays an important role in the IVM and both EGF and cysteamine have a stimulatory effect on further embryonic development in sheep. The maturation percentage recorded in the EGF supplemented medium (84.9\%) was significantly higher than in the cysteamine supplemented (69.6\%) and control medium $(67.2 \%)$. The fertilization and cleavage rates recorded were $73.7 \%$, $49.5 \%$ in control, $72.3 \%, 52.7 \%$ in cysteamine and $76.5 \%, 55.5 \%$ in EGF supplemented media respectively. The morula formation rate recorded in the EGF supplemented (38.7\%) and cysteamine supplemented $(36.7 \%)$ media was significantly higher, than in the control $(22.1 \%)$ medium.

The hyperthermia during oocyte maturation and/or fertilization adversely affects oocyte maturation and fertilization rates and retards further embryonic development [44]. The effects of supplementation of synthetic oviduct fluid (SOF) with glucose and Minimal Essential Medium (MEM) vitamins is assessed during the first step of the in vitro culture (SOFC1) of ovine zygotes has been experimented [45]. Vitamins must be present for optimal numbers of embryos to reach the blastocyst stage.

Interestingly the research was also conducted in this study and shown that, wheat peptones when supplemented during IVM, IVF and IVC did not improve the maturation rate and embryo yield for reasons which are unknown but the embryo yield improved when wheat peptone was supplemented only in IVC. However, further studies to determine the optimum concentration of wheat peptones as substitute for animal protein in embryo culture is needed to draw firm conclusions. The overall of this study showed the production of the sheep embryo from the ovaries of the slaughtered ewes and IVM, IVF of the oocytes and then IVC in complex culture media (CR1aa with 200 $\mu \mathrm{M}$ concentration of $\alpha$-tocopherol).

\section{Conclusion}

In the present work, a protocol has been established by IVM, IVF and IVC of sheep oocytes for in vitro production of sheep embryos. Studies on IVM, IVF and IVC using protein supplementation in different concentration are conducted to reveal the beneficial effects of protein supplements in embryo production.

\section{Acknowledgment}

Authors would like to thank management and staff of Chennai Fertility Centre, GITAM University, Dept. of animal Biotechnology, Tamilnadu Veterinary and Anima Sciences University, India for their kind support in bringing out the above literature and providing lab facilities. We also thank CMJ University for providing research support.

\section{References}

1. Dunn TG, Moss GE (1992) Effects of nutrient deficiencies and excesses on reproductive efficiency of livestock. J Anim Sci 70: 1580-1593.

2. Cheliak WM, Rogers DL (1990) Integrating biotechnology into tree improvement programs. Canadian journal of forest research 20: 452-463.

3. Baldassarre H, Furnus CC, DeMatos DG, Pessi H (1996) In vitro production of sheep embryos using laparoscopic folliculocentesis: alternative gonadotrophin treatments for stimulation of oocyte donors. Theriogenology 45: 707-717.

4. Brown BW, Radziewic T (1998) Production of sheep embryos in vitro and development of progeny following single and twin embryo transfers. Theriogenology 49: 1525-1536

5. Holm P, Walker SK, Seamark RF (1996) Embryo viability, duration of gestation and birth weight in sheep after transfer of in vitro matured and in vitro fertilized zygotes cultured in vitro or in vivo. J Reprod Fertil 107: 175-181.

6. Aubard Y, Piver P, Cogni Y, Fermeaux V, Poulin N, et al. (1999) Orthotopic and heterotopic autografts of frozen-thawed ovarian cortex in sheep. Hum Reprod 14: $2149-2154$.

7. Krogenæs A, Ropstad E, Thomassen R, Pedersen O, Forsberg M (1994) In vitro maturation and fertilization of oocytes from Norwegian semi-domestic reindeer (Rangifer tarandus). Theriogenology 41: 371-377.

8. Khatir $\mathrm{H}$, Anouassi A, Tibary A (2007) Quality and developmental ability of dromedary (Camelus dromedarius) embryos obtained by IVM/IVF, in vivo matured/IVF or in vivo matured/fertilized oocytes. Reprod Domest Anim 42: 263-270.

9. Wani NA, Wani GM, Khan MZ,. Salahudin S (2000) Effect of oocyte harvesting technique on in vitro maturation and in vitro fertilization in sheep. Small Rum Res 36: 63-67.

10. Farag IM, Girgis SM, Khalil WKB, Hassan NHA, Sakr AAM, et al. (2009) Effect of hormones, culture media and oocyte quality on in vitro maturation of Egyptian Sheep oocytes. J Appl Biosci 24: 1520-1534

11. Shabankareh HK, Zandi M (2010) Developmental potential of sheep oocytes cultured in different maturation media: effects of epidermal growth factor insulin-like growth factor I, and cysteamine. Fertil Steril 94: 335-340.

12. George F, Kerschen D, Van Nuffel A, Rees JF, Donnay I (2009) Plant protein hydrolysates (plant peptones) as substitutes for animal proteins in embryo culture medium. Reprod Fertil Dev 21: 587-598.

13. Snedecor GW, Cochran WG (1994) Statistical methods. Iowa State University Press, USA

14. Walker SK, Heard TM, Seamark RE (1992) In-vitro culture of sheep embryos without co-culture: successes and perspectives. Theriogenology 37: 111-126.

15. Wang S, Liu Y, Holyoak GR, Evans RC, Bunch TD (1998) A protocol for in vitro maturation and fertilization of sheep oocytes. Small Rum Res 29: 83-88. 
Citation: Sreenivas D, Kaladhar DSVGK, Yarla NS, Thomas VM, PalniSamy A (2013) Effect of Protein Supplementation on in vitro Maturation of Sheep Oocytes and in vitro Culture of Preimplantation with $\alpha$-Tocopherol Supplementation in CR1aa Medium on Sheep Embryos to the Blastocyst Stage. J Aller Ther 4: 133. doi:10.4172/2155-6121.1000133

16. Sreenivas D, Kaladhar DS, Samy AP, Kumar RS (2012) Understanding mechanism of in vitro maturation, fertilization and culture of sheep embryoes through in silico analysis. Bioinformation 8: 1030-1034.

17. Tao Y, Chen H, Tian NN, Huo DT, Li G, et al. (2010) Effects of L-ascorbic acid, alpha-tocopherol and co-culture on in vitro developmental potential of porcine cumulus cells free oocytes. Reprod Domest Anim 45: 19-25

18. Tao Y, Zhou B, Xia G, Wang F, Wu Z, et al. (2004) Exposure to L-ascorbic acid or alpha-tocopherol facilitates the development of porcine denuded oocytes from metaphase I to metaphase II and prevents cumulus cells from fragmentation. Reprod Domest Anim 39: 52-57.

19. Gstraunthaler G (2003) Alternatives to the use of fetal bovine serum: serumfree cell culture. ALTEX 20: 275-281.

20. Ghasemzadeh-Nava H, Tajik P (2000) In vitro maturation of ovine follicula oocytes in different concentrations of fetal calf serum and estrous sheep serum. Theriogenology 53: 435.

21. Wahid H, Gordon Cl, Sharif H, Longergan P, Gallagher M (1992) Effect and efficiency of recovery method for obtaining ovine follicular oocytes for in vitro procedures. Theriogenology 37: 318.

22. Wani NA, Wani GM, Khan MZ, Sidigi MA (1999) Effect of different factors on the recovery rate of oocytes for in vitro maturation and in vitro fertilization procedures in sheep. Small Rum Res 34: 71-76.

23. Shirazi A, Shams-Esfandabadi N, Hosseine SM (2005) A comparison of two recovery methods of ovine oocytes for in vitro maturation. Small Rum Res 58: 283-286.

24. Pawshe CH, Totey SM, Jain SK (1994) A comparison of three methods of recovery of goat oocytes for in vitro maturation and feritilization. Theriogenology 42: $117-125$

25. Schellander K, Fuhrer F, Brackett BG, Korb H, Schleger W (1990) In vitro fertilization and cleavage of bovine oocytes matured in medium supplemented with estrous cow serum. Theriogenology 33: 477-485.

26. Shirazi A, Shams-Esfandabadi N, Hosseine SM, Karimi I (2007) The presence of cumulus cells on nuclear maturation of sheep oocytes during in vitro maturation. Small Rum Res 68: 291-295.

27. Buccione R, Schroeder AC, Eppig JJ (1990) Interactions between somatic cells and germ cells throughout mammalian oogenesis. Biol Reprod 43: 543-547.

28. Mori T, Amano T, Shimizu H (2000) Roles of gap junctional communication of cumulus cells in cytoplasmic maturation of porcine oocytes cultured in vitro. Biol Reprod 62: 913-919.

29. Bavister BD, Leibfried ML, Lieberman G (1983) Development of preimplantation embryos of the golden hamster in a defined culture medium. Biol Reprod 28 : 235-247.

30. Ali A, Sirard MA (2002) Effect of the absence or presence of various protein supplements on further development of bovine oocytes during in vitro maturation. Biol Reprod 66: 901-905.
31. Yang X, Kubota C, Suzuki H, Taneja M, Bols PE, et al. (1998) Control of oocyte maturation in cows--biological factors. Theriogenology 49: 471-482.

32. George F, Daniaux C, Genicot G, Verhaeghe B, Lambert P, et al. (2008) Set up of a serum-free culture system for bovine embryos: embryo development and quality before and after transient transfer. Theriogenology 69: 612-623.

33. Paramio MT (2010) In vivo and in vitro embryo production in goats. Small Rum Res 89: 144-148.

34. Bavister BD (1995) Culture of preimplantation embryos: facts and artifacts Hum Reprod Update 1: 91-148.

35. Wang S, Liu Y, Holyoak GR, Bunch TD (1997) The effects of bovine serum albumin and fetal bovine serum on the development of pre- and postcleavagestage bovine embryos cultured in modified CR2 and M199 media. Anim Reprod Sci 48: 37-45.

36. Wrenzycki C, Herrmann D, Carnwath JW, Niemann H (1999) Alterations in the relative abundance of gene transcripts in preimplantation bovine embryos cultured in medium supplemented with either serum or PVA. Mol Reprod Dev 53: 8-18.

37. Wan PC, Hao ZD, Zhou P, Wu Y, Yang L, et al. (2009) Effects of SOF and CR1 media on developmental competence and cell apoptosis of ovine in vitro fertilization embryos. Anim Reprod Sci 114: 279-288.

38. Tajik P, Esfandabadi NS (2003) In vitro maturation of caprine oocytes in different culture media. Small Rum Res 47: 155-158.

39. Heidemann R, Zhang C, Qi H, Larrick Rule J, Rozales C, et al. (2000) The use of peptones as medium additives for the production of a recombinant therapeutic protein in high density perfusion cultures of mammalian cells. Cytotechnology 32: 157-167.

40. Kaladhar DSVGK, Chandra SP, Nageswara RPV, Krishna CA, Govinda RD et al. (2012) Protein interaction networks in MetalloProteins and Docking approaches of Metallic Compounds with TIMP and MMP in Control of MAPK Pathway, LDDD 10: 49-55.

41. George F, Vrancken M, Verhaeghe B, Verhoeye F, Schneider YJ, et al. (2006) Freezing of in vitro produced bovine embryos in animal protein-free medium containing vegetal peptones. Theriogenology 66: 1381-1390.

42. Grad I, Gajda B, Smorag Z (2010) Effect of plant protein supplementation on in vitro development of porcine embryos. Anim Sci Pap Rep 28: 271-279.

43. Wani AR, Khan MZ, Sofi KA, Lone FA, Malik AA, et al. (2012) Effect of cysteamine and epidermal growth factor (EGF) supplementation in maturation medium on in vitro maturation, fertilization and culturing of embryos in sheep. Small Rum Res 106: 160-164.

44. Sugiyama S, McGowan M, Phillips N, Kafi M, Young M (2007) Effects of increased ambient temperature during IVM and/or IVF on the in vitro development of bovine zygotes. Reprod Domest Anim 42: 271-274

45. Karami SH, Akhondi M (2012) Effect of glucose levels and MEM vitamins during the first step of IVC in synthetic oviduct fluid medium on in vitro development of ovine zygotes. Small Rum Res 106: 54-58. 